\title{
Designing PISA-like Mathematics Task to Assess Students' Mathematical Literacy
}

\author{
Isnaeni Umi Machromah", Sutama, Harun Joko Prayitno, Nuqthy Faiziyah, \\ Lina Wahyu Sri Fatmasari \\ Faculty of Teacher Training and Education, Universitas Muhammadiyah Surakarta (UMS), Surakarta, Indonesia
}

Received January 6, 2020 ; Revised June 18, 2020; Accepted June 27, 2020

\section{Cite This Paper in the following Citation Styles}

(a): [1] Isnaeni Umi Machromah, Sutama, Harun Joko Prayitno, Nuqthy Faiziyah, Lina Wahyu Sri Fatmasari , "Designing PISA-like Mathematics Task to Assess Students' Mathematical Literacy," Universal Journal of Educational Research, Vol. 8, No. 10, pp. 4986 - 4995, 2020. DOI: 10.13189/ujer.2020.081072.

(b): Isnaeni Umi Machromah, Sutama, Harun Joko Prayitno, Nuqthy Faiziyah, Lina Wahyu Sri Fatmasari (2020). Designing PISA-like Mathematics Task to Assess Students’ Mathematical Literacy. Universal Journal of Educational Research, 8(10), 4986 - 4995. DOI: 10.13189/ujer.2020.081072.

Copyright $\bigcirc 2020$ by authors, all rights reserved. Authors agree that this article remains permanently open access under the terms of the Creative Commons Attribution License 4.0 International License

\begin{abstract}
PISA is an ongoing program that monitors trends in the knowledge and skills that students around the world have acquired. Mathematics becomes one of the domains PISA assessed. Therefore, mathematical literacy is very essential. Indonesia, however, gets a low rank in PISA 2012 and 2015. This study is part of research and development research focusing on the preliminary and developing stage. This research aims to develop a PISA-like mathematics task for increasing students' literacy-related mathematics. The research subject is mathematics teachers and students in SMP Muhammadiyah in Boyolali Regency and also expertise in education. At this stage, the data are collected by observation and documentation. This study uses investigator triangulation. The result shows that mathematics material in junior high school can be developed as PISA-like problems as it includes quantity; space and shape; change and relationship; and uncertainty and data suitable with content in PISA. Moreover, this research produces for PISA-like tasks in each content and the context is related to Indonesia culture, namely technology trends in Indonesian teenagers, Cakra Menggilingan Ferris Wheel in Yogyakarta, Polygon Bicycle as a popular brand of Indonesia that known overseas, and Leather Craft as Indonesian local wisdom. PISA-like tasks based on Indonesian content could assess mathematical literacy.
\end{abstract}

Keywords Mathematical Literacy, Mathematics Task,
PISA-like, Local Wisdom

\section{Introduction}

Mathematics learning is often monotonous and non-interactive teaching and learning activity. Students are often reluctant to follow the learning process. Mathematics is a subject that is assessed in national examinations and PISA (Program for International Student Assessment) studies. PISA will require students to have higher thinking skills, by combining their knowledge in solving mathematical problems (Wardhani, 2004). The focus of PISA is the emphasis on the skills and competencies of students acquired from school and used in daily life with a variety of situations (OECD, 2013). Mathematics is a science that has a very strong attachment to everyday life. (Ker, 2013) states that good mathematical skills are one of the basics in developing the latest and sophisticated technology. Therefore, mathematics is a basic and dynamic subject given in school to students to increase their understanding of the world and make their value in social life (Yore, Anderson, \& Hung Chiu, 2010).

Based on the results of the PISA analysis over the past 3 periods, Indonesian students still on the 10 lowest ranks especially in mathematical literacy. Based on the PISA result, Indonesian students got rank 72 from 78 countries in 
2018, while in 2015 they got rank 63 from 72 countries, and got rank 64 from 65 countries in 202. Indonesian students are only able to answer PISA questions levels 1, 2, and 3, and only a few students can complete level 4 questions (Edo, Hartono, \& Putri, 2013). Wardhani (2004) stated that the cause of the weak ability of students to solve PISA problems is that students are not used to the process of solving problems correctly, namely by stages of understanding problems, planning, problem-solving, and checking the results. Students often have a low ability to understand problems. Students will more easily understand the problems that are often encountered because students will use procedures that are often used, but if students encounter a type of question that they have never encountered, students will find it difficult to solve these problems. Students are not able to solve new types of questions because students do not know the procedure for solving these problems. In the PISA problem, there are several materials used as a reference to measure the level of mathematical problem-solving ability. Therefore, Indonesia has a low score in the PISA assessment each period.

Stacey (2010) argues that the concept of literacy is closely related to several concepts discussed in mathematics education. The PISA mathematics literacy domain relates to students' capacity to analyze, reason, and communicate ideas effectively as they propose, formulate, solve and interpret mathematical problems in various situations (Edo et al., 2013). The fact shows that mathematics literacy skills have not been trained to the full. This is very reasonable because there are no available questions that measure students' mathematical literacy abilities. There are several sources of obstacles faced by teachers in assessing mathematics literacy, namely: first, the lack of teacher knowledge about mathematical literacy competencies; secondly there is no mathematical literacy assessment format especially in schools; the third is that mathematics literacy competitions are rarely conducted, so teachers do not direct their learning towards mathematical literacy, only to achieve material goals. Based on Pulungan (2014), there is no mathematical literacy test in school yet, especially for junior and senior high school students. Moreover, it is needed to develop a mathematical literacy instrument integrated into learning to make students understand and close to the test (Pulungan, 2014). Thus, it is needed to develop a PISA-like mathematics task-based to introduce and assess students' mathematical literacy.

An assessment carried out through using non-standardized instruments is one of the factors not yet fulfilled the purpose of educational assessment (Hamid, 2010). Learning assessment shows various procedures for obtaining student learning information and determining decisions related to student performance or learning outcomes (Miller, Linn, \& Gronlund, 2012). Sugiyono (2009) states that products that are rarely developed to improve the quality of education are learning assessment instruments. The development of learning assessment instruments is an effort to develop assessment instruments based on needs analysis into new products by first testing their effectiveness so that they produce products that function and benefit the community (Wijayanti, Sukestiyarno, \& Masrukhi, 2015). The development of learning assessment instruments aims to improve students' knowledge and understanding of learning material. One of the developments of assessment instruments can be done by making quality questions. Questions can be said to be of quality when the questions can measure what is to be measured and the questions must be aligned with the learning objectives achieved (Uno, 2008).

Some research had developed mathematics problems based on PISA characteristics. Some of them developed PISA problems by translating the PISA test to the Indonesian language, such as research conducted by Pangestika \& Murtiyasa (2016). It was needed by some modification on the PISA test that would be used for Indonesian students as the characteristics of stimulation might be different from Indonesian cultures, such as the currency, demographical, and other special conditions. The positive side is that it would assess students' mathematical literacy appropriately like the real PISA test. Besides, some researcher designed PISA-like problems based on some region in Indonesia, such as Jambi context (Charmila, Zulkardi, \& Darmawijoyo, 2016), Lampung context (Putra, Zulkardi, \& Hartono, 2016), and Bangka context (Dasaprawira, Zulkardi, \& Susanti, 2019). Using local content as mathematics problems would make the student more motivate and closer to problems as well as understand the context of the problems. However, if the content is very specific in a certain region, then the problems could not be used for other students in other regions. Hence, this study would develop a PISA-like task based on the Indonesian context in general, so that students in the various region could use this instrument. Based on the background above, this research is aimed at developing a PISA-oriented assessment instrument model in Boyolali Regency, Central Java, which effectively improves mathematics learning outcomes in Junior High School students in Boyolali Regency, Central Java.

\section{Research Methods}

This research was conducted by research and development design which aimed to develop mathematics assessment based on PISA criteria in Boyolali to assess the mathematical literacy of students. Besides, the design of this research is qualitative and qualitative with the ADDIE model, namely analysis, design, development, implementation, and evaluation. This article was focusing on analysis, design, and development stages. The subject of this research consists of mathematics teachers and students in SMP Muhammadiyah in Boyolali Regency and also expertise in education, while the object was PISA-like task 
and mathematical literacy. Besides, in this research, the data was collected through observation, interviews, documentation, test, and questionnaire. Moreover, this research also used focus group discussion (FGD) as an additional data collection method. Data analysis of this study was qualitative by using flowchart type and descriptive comparison. There were three main stages of this study, namely identification of theoretical review, design the instrument based on PISA, and focus group discussion.

\section{Results and Discussion}

This research had produced four mathematics problems based on PISA including quantity contents, change and relationship contents, space and shape contents, and also uncertainty and data contents. There were 11 questions related to contents. Each content had its themes, namely Bianglala (Ferris Wheel), Peralatan Elektronik (Electronic Tools), Sepeda Polygon (Bicycle Polygon), and Kerajinan Kulit (Leather Craft).

The researcher designed PISA-like mathematics problems involved four mathematical content in PISA. The first step was making an assessment grid consisting of content, PISA problem 2012, material, context, and questions. Each content had its context that adopted by the PISA problem 2012 and was modified based on the Indonesian context. The assessment grid is presented in the following table.

Table 1. Assessment Grid of PISA-like mathematics problems.

\begin{tabular}{|c|c|c|c|c|}
\hline Content & $\begin{array}{l}\text { PISA } \\
\text { Problems } \\
2012\end{array}$ & Material & Context & Questions \\
\hline \multirow{3}{*}{ Quantity } & \multirow{3}{*}{ MP3 Players } & \multirow{3}{*}{$\begin{array}{l}\text { Social } \\
\text { Arithmetics }\end{array}$} & \multirow{3}{*}{$\begin{array}{l}\text { Peralatan Elektronik } \\
\text { (Electronic Tools) }\end{array}$} & $\begin{array}{l}\text { Presented the data about the price of some goods and some } \\
\text { statements related to the purchase of goods such. Students } \\
\text { are asked to identify the statements are true and false }\end{array}$ \\
\hline & & & & $\begin{array}{l}\text { Presented the data on the price of some goods and } \\
\text { statements related discounts are given. If given some } \\
\text { money, students can determine the goods which course that } \\
\text { can be bought and not to be bought. }\end{array}$ \\
\hline & & & & $\begin{array}{l}\text { Given the data related to the price of the sale, the price of } \\
\text { buying, and profit. Students are asked to formulate an } \\
\text { appropriate equation. }\end{array}$ \\
\hline \multirow{2}{*}{$\begin{array}{l}\text { Space and } \\
\text { Shape }\end{array}$} & \multirow{2}{*}{ Ferris Wheel } & \multirow{2}{*}{ Circle } & \multirow{2}{*}{$\begin{array}{l}\text { Bianglala (Ferris } \\
\text { Wheel) }\end{array}$} & $\begin{array}{l}\text { Presented Ferris wheel image, which shows the shape of a } \\
\text { circle. Students are asked to specify the high point of the } \\
\text { center of the Ferris wheel on the surface of the ground if the } \\
\text { known high maximum of the wheel. }\end{array}$ \\
\hline & & & & $\begin{array}{l}\text { Given the data related to the time that it takes Ferris wheel } \\
\text { rotates one lap. Students are interested in determining the } \\
\text { final position if it is known that the Ferris wheel has rotated } \\
\text { at a certain time. }\end{array}$ \\
\hline \multirow{3}{*}{$\begin{array}{l}\text { Change and } \\
\text { Relationship }\end{array}$} & \multirow{3}{*}{$\begin{array}{l}\text { Helen The } \\
\text { Cyclist }\end{array}$} & \multirow{3}{*}{$\begin{array}{l}\text { Speed, } \\
\text { Distance, and } \\
\text { Time }\end{array}$} & \multirow{3}{*}{$\begin{array}{l}\text { Sepeda Polygon } \\
\text { (Polygon Bicycle) }\end{array}$} & $\begin{array}{l}\text { Given distance and time data. Students are asked to } \\
\text { determine an average speed based on data. }\end{array}$ \\
\hline & & & & $\begin{array}{l}\text { Presented data are related to distance and speed, as well as } \\
\text { several statements about travel time. Students are asked to } \\
\text { identify statements that correspond. }\end{array}$ \\
\hline & & & & $\begin{array}{l}\text { Given the data comparison of distance and time, students } \\
\text { are asked to determine the average speed. }\end{array}$ \\
\hline \multirow{3}{*}{ Uncertainty } & \multirow{3}{*}{ Faulty Players } & \multirow{3}{*}{$\begin{array}{c}\text { Data } \\
\text { Presentation }\end{array}$} & \multirow{3}{*}{$\begin{array}{l}\text { Kerajinan Kulit } \\
\text { (Leather Craft) }\end{array}$} & $\begin{array}{l}\text { Presented data on leathercraft production and the } \\
\text { percentage of production failures due to defects. Students } \\
\text { asked to analyze the statements are given whether by the } \\
\text { data or not. }\end{array}$ \\
\hline & & & & $\begin{array}{l}\text { Given a statement assembled average production of } \\
\text { leathercraft. Students are asked to analyze the statements } \\
\text { and explain them. }\end{array}$ \\
\hline & & & & $\begin{array}{l}\text { Presented the data comparison of the data early. Students } \\
\text { are asked to identify the percentage of production } \\
\text { leathercraft. }\end{array}$ \\
\hline
\end{tabular}


The first content is quantity. At this content, the task was adopted from PISA question 2012, especially in the "MP3 Players" context presenting in Figure 1. The stimulation of problems is presented in Figure 1. Based on the figure, it can be seen that there are 3 items related to an MP3 player, namely MP3 player, headphones, and speakers. Besides, each item is followed by the prize in zeds. The first question presents the amount of the price and some possible cases related to the amount of the price. Then, students are asked to analyze the reason why the calculation is wrong. In the second question, data information is added with a discount for special terms. Students are asked to identify which statements are correct if someone only has some money. In the third question, the stimulation is added to data related to profit. Students are asked to identify which is an appropriate equation based on the data given.

As the problem would be used for Junior High School Students in Boyolali, Indonesia, then the stimulation should be modified and coincide with the context of Indonesia at this time and is presented in Figure 2. We choose a power bank, earphone, and smartphone case as the items as those items close for teenagers. Besides, we change the prize in rupiahs too. It would be predicted that students would be confused with the zeds unit. The main problem is almost similar to the PISA problem; it provides three items with the price, then students should analyze some cases.

\section{MP3 PLAYERS}

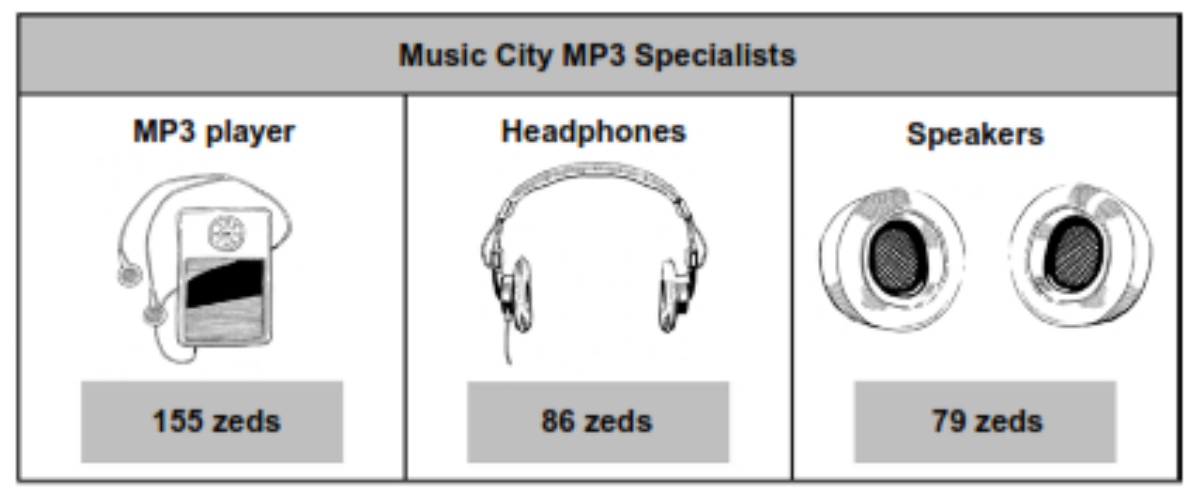

Figure 1. PISA 2012 task in context MP3 Players.

Tika mendapatkan hadiah sebuah smartpone dari Ayah karena ia telah giat belajar dan memperoleh nilai yang memuaskan pada ujian nasional. Untuk melengkapai penggunaan smartphone, Tika ingin membeli barang lain seperti power bank, earphone, dan smartphone case.

\begin{tabular}{|c|c|c|}
\hline Power bank & Earphone & Smartphone Case \\
\hline & & \\
\hline$R$
\end{tabular}

Figure 2. A PISA-like task in context Electronic Tools 
The second content is associated with space and shape content. This task was adopted from the content "Ferris Wheel” context on PISA 2012. The stimulation of the task is high of giant Ferris Wheel from the river. There are 2 pictures presented that show the real Ferris Wheel and the sketch of its high. The main problems are the diameter of the Ferris Wheel, and where is the position of people if the Ferris Wheel rotates at a certain time.

Figure 3 shows the PISA-like task-related space and shape content in the Indonesian Ferris Wheel context. It used the Cakra Manggilingan Ferris Wheel that was one of the highest Ferris Wheel in Indonesia. The stimulation focused on information about Cakra Manggilingan. The problems, however, are similar to the PISA test that determines the diameter of the Ferris Wheel and determines position after the Ferris Wheel rotating in a certain time. As it used real Ferris Wheel in Indonesia, then the data were also taken from the real measurement.
Therefore, this task was modified by changing the context with Indonesia Ferris Wheel and also changing the data based on the real.

The first question is determining the high of its center if the information given related to the highest point and its high above the bed of the river (Figure 4). This problem includes employing the process on the PISA test as it applies mathematical facts or concepts when finding a solution (OECD, 2019). The second question is determining people's position while riding the wheel if the duration of a wheel is known in one rotation. This problem includes the formulating process on the PISA test. One of the characteristics from formulating is understanding and explaining the relationships between the context-specific language of a problem and the symbolic and formal language needed to represent it mathematically (OECD, 2019).

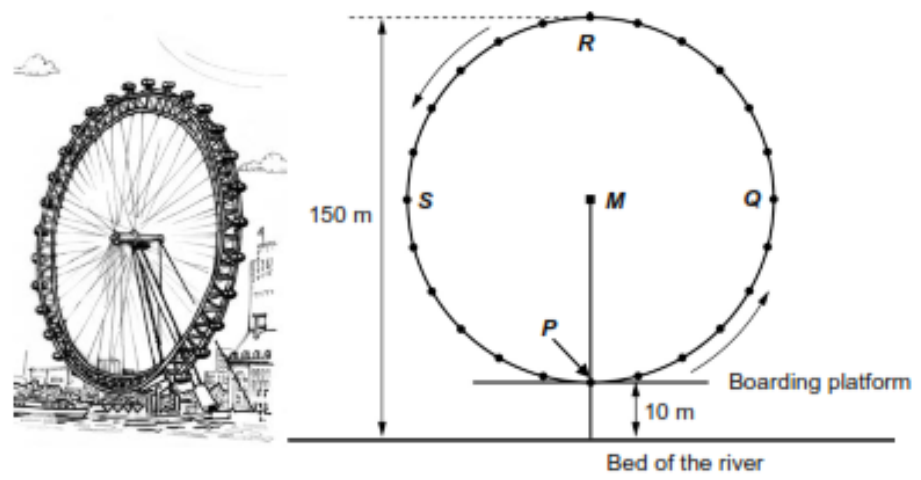

Figure 3. PISA 2012 task in context Ferris Wheel

\section{BIANGLALA CAKRA MANGGILINGAN}

Pernahkah kalian naik wahana bianglala? Bianglala Cakra Manggilingan merupakan bianglala tertinggi di Indonesia. Cakra Manggilingan diambil dari Bahasa Jawa yang berarti roda kehidupan yang terus berputar. Bianglala Cakra Manggilingan ini terletak di atas kolam renang Sindu Kusuma Edupark, Sleman, Yogyakarta.

Perhatikan gambar dan diagram berkut.
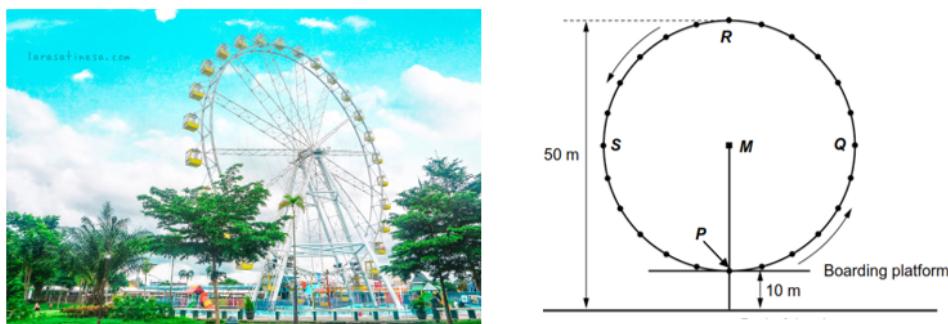

Gambar: Bianglala Cakra Manggilingan dan Sketsa

Wahana bianglala Cakra Manggilingan memiliki titik tertinngi 50 meter di atas permukaan tanah dan ketinggian terendah berada pada 3 meter di atas permukaan tanah. Bianglala ini berputar searah dengan panah pada diagaram tersebut. 


\section{SEPEDA POLYGON}

Bayu baru saja memperoleh hadiah sepeda Polygon Xtrada terbaru dari Ayah. Sepeda itu dilengkapi dengan speedometer pada bagian stang sepeda. Speedometer tersebut dapat menunjukkan jarak tempuh dan kecepatan rata-rata dalam sebuah perjalanan.

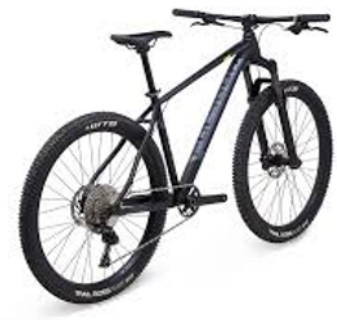

Taukah kalian?

Polygon merupakan salah satu merk sepeda terbaik di dunia. Tidak banyak yang tahu bahwa

Polygon merupakan sepeda buatan asli Indonesia. Pabrik sepeda ini berada di Sidoarjo, Jawa

Timur dengan nama perusahaan PT Insera Sena dan mulai produksi sejak tahun 1989 hingga

sekarang.

Figure 5. The PISA-like task in context Polygon Bicycle.

The third content is associated with change and relationship content. This task was adopted from the content "HELEN THE CYCLIST" context on PISA 2012. The stimulation of the task is that Helen got a new bike which has a speedometer on the handlebar. There are three problems related to speed average, time, and distance.

Figure 5 presents a PISA-like task in change and relationship content, especially in context Polygon Bicycle. As this task was adopted from Helen The Cyclist context, then Polygon Bicycle was chosen as one of the popular bicycles' brands in Indonesia and overseas. The aim was to inform students that the Indonesian product was so great that could be sold internationally. The questions given are also similar to the PISA test solving the problems associated with average speed, time, and distance. All three questions involve personal context and employ process. This employ process is related to devise and implement strategies for finding mathematical solutions as well as apply mathematical facts to finding the solutions.

The fourth content is associated with uncertainty and data content. This task was adopted from the content "FAULTY PLAYERS" context on PISA 2012. The stimulation of the task is associated with the production of electronic tools in a company. The data presented in the table consist of the average number of production and the percentage of faulty from two types of electronic tools. The students are asked to identify the appropriate statement associated with data.

Figure 6 presents a PISA-like task in uncertainty and content, especially in context Leather Craft. As the task from PISA in the Faulty Players context was very challenging, then we tried to adopt it in the Indonesian context. LeatherCraft context was chosen as this is one of the popular and traditional stuff in Indonesia. The stimulation of this task is introducing leather craft from Magetan as one of local wisdom in Indonesia. The data given is similar to the Faulty Players context in PISA with modification based on the real data and it presents on the table.

The first problem is identifying a suitable statement based on the data given. This task process involves formulating as it is representing a problem in a different way, including organizing it according to mathematical concepts and making appropriate assumptions (OECD, 2019). The second problem is evaluating the statement given related to data. This task has interpreted the process because it was evaluating the reasonableness of a mathematical solution in the context of a real-world problem (OECD, 2019). The third problem is to add another data from other cities in Indonesia. Students are asked to analyze which has a lower percentage of the faulty product. This task also involves the formulating process as reflecting on mathematical arguments and explaining and justifying mathematical results. 
Sentra Kerajinan Kulit Magetan

Kabupaten Magetan sangat terkenal dengan sentra kerajinan kulit. Industri kulit di Magetan merupakan salah satu yang tertua di Indonesia. Saat ini, terdapat lebih dari 115 unit Usaha Kecil Menengah (UKM) yang menghasilkan berbagai produk berbahan kulit seperti sepatu, tas, dompet, jaket, ikat pinggang, dan berbagai aksesoris. Produk yang paling banyak diminati pengunjung adalah tas dan sepatu.

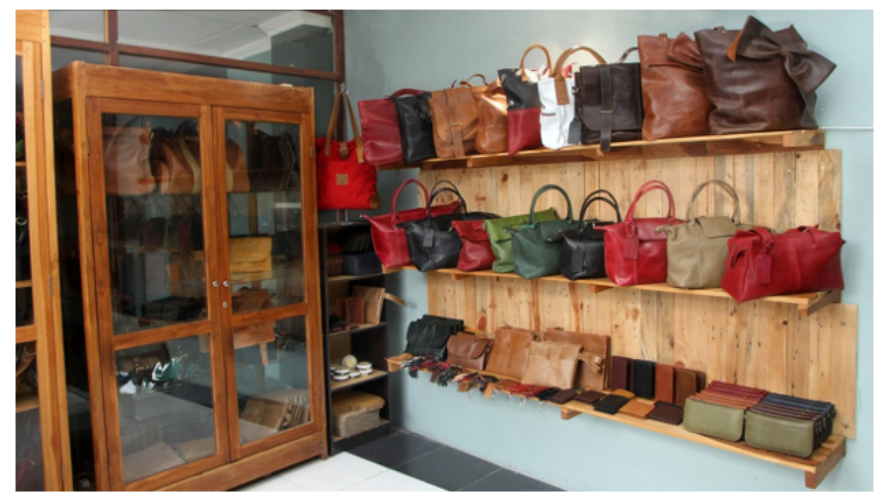

Untuk menjaga kualitas produk tetap baik, diperlukan pengontrolan kualitas, atau dikenal sebagai quality control terhadap barang yang dihasilkan. Jika terdapat barang yang memiliki cacat, akan disortir untuk diperbaiki atau dijual dengan harga yang lebih murah.

Figure 6. A PISA-like task in context Leather Craft.

Using the Indonesian context on mathematics problems has many benefits for students. Students are very happy with learning materials that contain interactive and regional content (Abadi, Asih, \& Jupri, 2018). Students find it easier to understand the content of the material and students feel more excited and motivated in learning activities. (Bahri, Kusumawati, \& Nuraini, 2017). Integrating local wisdom values of local people in learning could improve the mood and bring it closer to the students (Anwarudin \& Dafik, 2019). Local wisdom-oriented problem-solving learning models are effective to improve mathematical problem-solving ability (Parwati, Sudiarta, Mariawan, \& Widiana, 2018). The values of local wisdom can be a potential to develop assessment and remedial (Toharudin \& Kurniawan, 2017). Since this task was developed based on the Indonesian context, and then it would give a positive impact on students. They would feel motivated, excited, and challenging because the task is closer to their life.

Various context of PISA-like was developed based on Indonesian content, namely Jambi context (Charmila et al., 2016), Lampung context (Putra et al., 2016), Bangka context (Dasaprawira et al., 2019), cultural heritage (Oktiningrum, Zulkardi, \& Hartono, 2016), Asian Games (Nizar, Putri, \& Zulkardi, 2018). Some of them using regional context that could not be used in other regions. Thus, designing PISA-like based on Indonesian content, in general, would be more flexible. Designing of mathematics based on local wisdom affects the knowledge and character of learners in the area (Zulfah, 2018). Developing a PISA-like task based on Indonesian culture or condition would be potential effects on students' interest and elicit students' mathematical competencies as mentioned in the PISA framework. (Zulkardi \& Kohar, 2018). This PISA-like task was developed in the general context of Indonesia so that students in the various region could understand and solve the problems.

Using specific content related to students' life gives a great effect on their problems solving ability. There is a comparison of students' mathematical literacy in solving PISA-like with local wisdom and the original task of PISA.

It can be seen in figure 7 that using local content on PISA-like tasks gives the greater result on their mathematical literacy skill. This limited test is analyzed based on the mathematical literacy indicators, namely communicating, analyze, and reasoning. There is around $83 \%$ of students have communicating indicators based on the PISA-like task and only 58\% of students have communicating indicators based on the original PISA task. Besides, The analysis aspect is reached by a half students in the PISA-like task and it is $6 \%$ greater than in the PISA task. Moreover, only around $17 \%$ of students fulfill the reasoning aspect of the original PISA task and about two times that students solve the reasoning aspect of the PISA-like task. This small scale trial showed that using local contexts such as our culture, local wisdom, and regional specialties give a more positive impact on the mathematical literacy skill of students. 


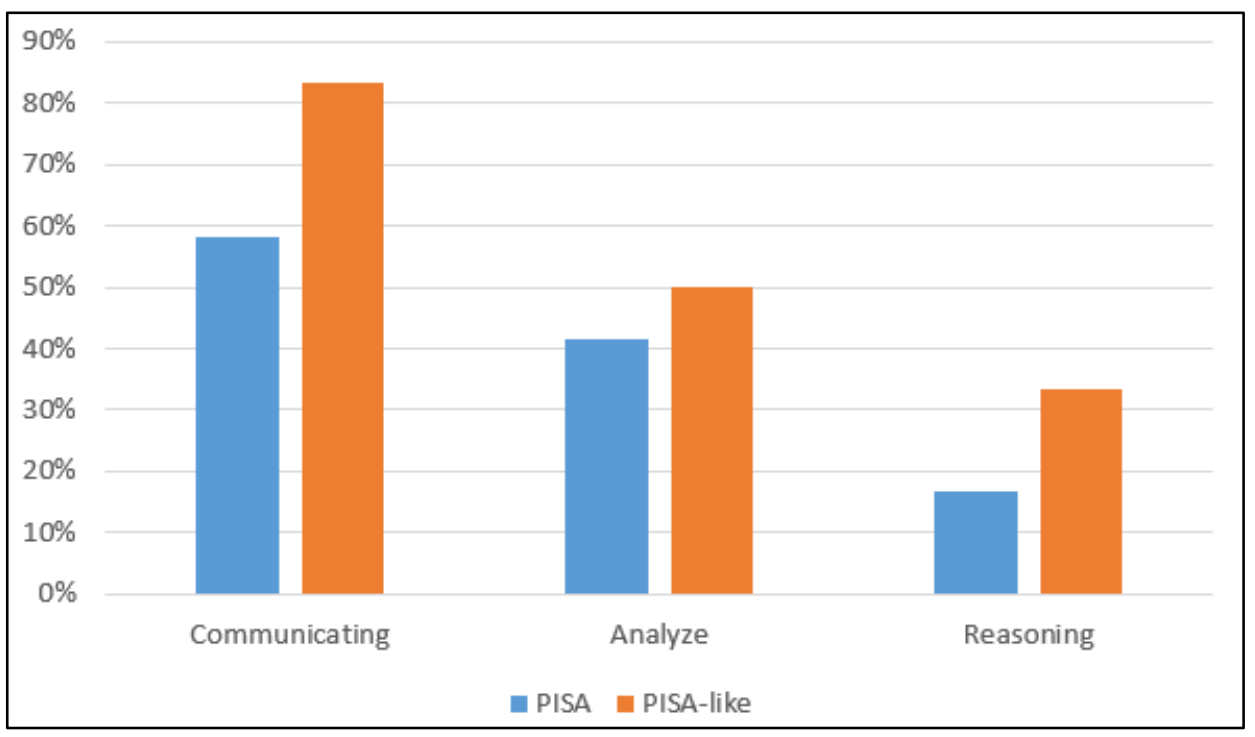

Figure 7. Comparison of Mathematical Literacy Skills of Students

Another research is in line with this comparison. Research conducted by Rahmawati, Annajmi., \& Hardianto (2015) uses the original PISA task in levels 1 to 6 to identify students' abilities related to mathematics. The results showed that only $50 \%$ of students solved the PISA task in level 1 as the lack of ability to solve a problem in general context; only 50\% students solved level 3 as they cannot understand and represent the problems to their knowledge as the problems are uncommon for them, and there are no students could solve the level 5 because they have no idea to solve complex and complicated problems. Also, there is $29.55 \%$ of students fulfill mathematics literacy indicators on solving PISA tasks 2015 (Saputro \& Murtiyasa, 2018). The majority of students do not have mathematical literacy skills yet, especially as they cannot evaluate the results and some of them have difficulties in doing mathematics modeling from the problems. It shows that the original PISA task stull challenging for many students in the context is more general and uncommon for them. On the other hand, using local context on developing the PISA task gives a positive impact. For example, students could use and develop their fundamental mathematics concepts to solve various problems. The task stimulate students to use their critical thinking ability and reasoning skills, students got more motivation to solve the problems related to Jambi city, and the task can be used to enrich students' mathematical literacy (Charmila et al., 2016). Using PISA-like tasks on familiar contexts such as potential effect on Asian Games shows the capability of communication and representation (Nizar et al., 2018). Moreover, the PISA tasks that developed based on local heritage and Indonesian culture have potentially effect to the students' mathematical literacy in activating the indicators of each fundamental mathematical capability (Oktiningrum et al., 2016). Based on that research, using local context on PISA-like tasks gives a more positive impact for students, especially on their mathematical literacy skills, than using the original PISA task as it is quite unfamiliar for students.

The mathematical literacy skill in PMRI learning can be improved by rediscovering the concept of mathematics. The PISA-like task could encourage students' mathematical literacy in terms of reasoning and contextual. One approach of mathematics learning that can have a positive impact on students' literacy skills is the Realistic Mathematics Approach (RME) (Dianawati, 2018). PMRI approach with character education and PISA-like assessments is effective in improving students' mathematical literacy skills (Wardono \& Kurniasih, 2015). Learning with a contextual approach can develop mathematical literacy mainly on process employing and interpreting (Mulyono \& Lestari, 2016). As this PISA-like task was designed by using realistic problems, especially the Indonesian context, then this task would be in an alternative way to measure students' mathematical literacy.

\section{Conclusions}

It is still needed to develop a mathematics task based on local wisdom and oriented to the PISA test. Mathematics material in junior high school could be developed as PISA-like problems as it included quantity; space and shape; change and relationship; and uncertainty and data suitable with content in PISA. Moreover, this research produced a PISA-like task in each content that consisted of social arithmetic; circle; distance, speed, and time; and also data presentation. Besides, the context was related to Indonesia culture, namely technology trends in Indonesian teenagers, Cakra Manggilingan Ferris Wheel in Yogyakarta, Polygon Bicycle as a popular brand of Indonesia that is known overseas, and Leather Craft as 
Indonesian local wisdom. PISA-like tasks based on Indonesian content could assess mathematical literacy.

\section{REFERENCES}

[1] Abadi, M. K., Asih, E. C. M., \& Jupri, A. (2018). The Development of Interactive Mathematics Learning Material Based on Local Wisdom with .swf Format. Journal of Physics: Conference Series, 1013(1). https://doi.org/10.108 8/1742-6596/1013/1/012131

[2] Anwarudin, M., \& Dafik. (2019). The analysis of students' metacognition in solving local wisdom based mathematical problems and the application of murder strategy to increase their metacognition ability. IOP Conference Series: Earth and Environmental Science, 243(1). https://doi.org/10.1088 /1755-1315/243/1/012051

[3] Bahri, S., Kusumawati, L., \& Nuraini, L. (2017). STEAM Education Based On Local Wisdom Of Coffee Plantation In Jember To Improve The Competitiveness in the 21st Century. Pancaran Pendidikan, 6(3), 126-135. https://doi.org/10.25037/pancaran.v6i3.62

[4] Charmila, N., Zulkardi, \& Darmawijoyo. (2016). Pengembangan Soal Matematika Model PISA Menggunakan Konteks Jambi (Developing Mathematics Problems based on PISA Using Jambi Context). Jurnal Penelitian Dan Evaluasi Pendidikan, 20(2), 198-207.

[5] Dasaprawira, M. N., Zulkardi, \& Susanti, E. (2019). Developing mathematics questions of Pisa type using Bangka context. Journal on Mathematics Education, 10(2), 303-314. https://doi.org/10.22342/jme.10.2.5366.303-314

[6] Dianawati, R. N. (2018). PMRI Learning With Blended Learning Strategy to Improve Mathematical Literacy Skills. Unnes Journal of Mathematics Education Research, 7(1), 79-85.

[7] Edo, S. I., Hartono, Y., \& Putri, R. I. (2013). Investigating Secondary School Students Difficulties in Modeling Problems PISA-Model Level 5 and 6. IndoMS J.M.E, 4(1), 41-58.

[8] Hamid, S. (2010). Bahan Pelatihan Penguatan Methodologi Pembelajaran Berdasarkan Nilai-Nilai Budaya untuk Membentuk Daya Saing dan Karakter Bangsa: Pengembangan Pendidikan Budaya dan Karakter Bangsa (Training Material for Strengthening Learning Methodologies Based on Cultu. Jakarta: Kemendiknas Badan Penelitian dan Pengembangan Pusat Kurikulum.

[9] Ker, H. W. (2013). Trend Analysis of Mathematics Achievements: A Comparative Study Using TIMSS Data. Universal Journal of Educational Research, 1(3).

[10] Miller, M. D., Linn, R. L., \& Gronlund, N. E. (2012). Measurement and Assessment in Teaching. New Jersey: Pearson Higher Education.

[11] Mulyono, \& Lestari, D. I. (2016). The Analysis Of Mathematical Literacy And Self-Efficacy Of Students In Search, Solve, Create, And Share (SSCS) Learning With A Contextual Approach. International Conference on
Mathematics, Science, and Education, 2016(Icmse), M159M164.

[12] Nizar, H., Putri, R. I. I., \& Zulkardi. (2018). Developing PISA-like mathematics problem using the 2018 Asian Games football and table tennis context. Journal on Mathematics Education, 9(2), 183-194. https://doi.org/10.2 2342/jme.9.2.5246.183-194

[13] OECD. (2013). PISA 2012 Assessment and Analytical Framework: Mathematics, Reading, Science, Problem Solving, and Financial Literacy (PISA, Ed.). Paris: OECD Publishing.

[14] OECD. (2019). PISA 2018 Assessment and Analytical Framework (PISA, Ed.). https://doi.org/https://doi.org/10.1 787/b25efab8-en

[15] Oktiningrum, W., Zulkardi, \& Hartono, Y. (2016). Developing a PISA-like mathematics task with Indonesia's natural and cultural heritage as a context to assess students' mathematical literacy. Journal on Mathematics Education, 7(1), 1-8. https://doi.org/10.22342/jme.7.1.2812.1-8

[16] Pangestika, W. W., \& Murtiyasa, B. (2016). Pengembangan Soal Serupa Pisa Pada Konten Space and Shape Untuk Mengukur Kemampuan Penalaran Siswa (Development of Pisa-Like Problems in Space and Shape Content to Measure Students' Reasoning Capabilities). Prosiding Seminar Nasional Pendidikan Matematika 2016, 1-7. https://doi.org/10.1021/bi960768p

[17] Parwati, N. N., Sudiarta, I. G. P., Mariawan, I. M., \& Widiana, I. W. (2018). LOCAL WISDOM-ORIENTED PROBLEM-SOLVING LEARNING MODEL TO IMPROVE MATHEMATICAL PROBLEM-SOLVING ABILITY. Journal of Technology and Science Education, 8(4), 310-320.

[18] Pulungan, D. A. (2014). Pengembangan Instrumen Tes Literasi Matematika Model PISA (Developing Instrument of Mathematical Literacy Test Based on PISA Model). Journal of Educational Research and Evaluation, 3(2), 2-6.

[19] Putra, Y. Y., Zulkardi, Z., \& Hartono, Y. (2016). Pengembangan Soal Matematika Model PISA Level 4, 5, 6 Menggunakan Konteks Lampung (Developing Mathematics Problems PISA Model on Level 4, 5, and 6 Using Lampung Context). Kreano, Jurnal Matematika Kreatif-Inovatif, 7(1), 10-16. https://doi.org/10.15294/kreano.v7i1.4832

[20] Rahmawati, E., Annajmi., \& Hardianto. (2015). Analisis Kemampuan Matematis Siswa Smp Dalam Menyelesaikan Soal Matematika Bertipe Pisa. Jurnal Pendidikan Matematika, (1), 1-5.

[21] Saputro, R., \& Murtiyasa, B. (2018). Analisis Kemampuan Literasi Matematika Siswa dalam Menyelesaikan Soal Tipe PISA 2015.

[22] Stacey, K. (2010). Mathematical and Scientific Literacy around the World. Journal of Science and Mathematics Education in Southeast Asia, 33(1), 1-16.

[23] Sugiyono. (2009). Metode Penelitian Pendidikan Pendekatan Kuantitatif, Kualitatif, dan $R \& D$ (Educational Research Methods Quantitative, Qualitative Approaches, and $R \& D)$. Bandung: Alfabeta.

[24] Toharudin, U., \& Kurniawan, I. S. (2017). Values of Local 
Wisdom: A Potential to Develop an Assessment and Remedial. International Journal of Evaluation and Research in Education (IJERE), 6(1), 71. https://doi.org/10.11591/ije re.v6i1.6349

[25] Uno, H. (2008). Perencanaan Pembelajaran. Jakarta: PT Bumi Aksara.

[26] Wardhani, S. (2004). Permasalahan Kontekstual Mengenalkan Bentuk Aljabar di SMP (Contextual Problems Introducing Forms of Algebra in Middle School). In Paket Pembinaan Penataran. Yogyakarta: Departement Pendidikan Nasional Direktorat Jendral Pendidikan Dasar Menengah Pusat Pengembangan Penataran Guru Matematika.

[27] Wardono, \& Kurniasih, A. W. (2015). Peningkatan Literasi Matematika Mahasiswa Melalui Pembelajaran Inovatif Realistik E-Learning Edmodo Bermuatan Karakter Cerdas Kreatif Mandiri ( Improvement of Student Mathematics Literacy Through Innovative Realistic Learning Edmodo with Independent Creat. Kreano: Jurnal Matematika Kreatif-Inovatif, 6(1), 95-102. https://doi.org/10.15294/kre ano.v6i1.4978

[28] Wijayanti, T., Sukestiyarno, \& Masrukhi. (2015).
Implementasi Penilaian Kemampuan Berfikir Kritis dan Karakter Demokratis pada Materi Sistem Politik Indonesia dengan Metode Pembelajaran Role Playing Berbasis Konservasi (Implementation of Critical and Democratic Critical Ability Assessment in The Politic. Jurnal of Educational and Evaluation, 6(1), 10-18. Retrieved from https://journal.unnes.ac.id/sju/index.php/jere/article/view/1 334

[29] Yore, L. D., Anderson, J. O., \& Hung Chiu, M. (2010). Moving PISA Results into the Policy Arena: Perspectives on Knowledge Transfer for Future Considerations and Preparations. International Journal of Science and Mathematics Education, 8, 593-609.

[30] Zulfah, Z. (2018). Analisis Kebutuhan Pengembangan Soal Berbasis Kearifan Lokal (Analysis of Local Wisdom-Based Problem Development Needs). Jurnal Cendekia: Jurnal Pendidikan Matematika, 2(1), 1-6. https://doi.org/10.31004 /cendekia.v2i1.27

[31] Zulkardi, Z., \& Kohar, A. W. (2018). Designing PISA-Like Mathematics Tasks in Indonesia: Experiences and Challenges. Journal of Physics: Conference Series, 947(1). https://doi.org/10.1088/1742-6596/947/1/012015 